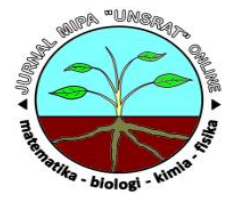

\title{
Keanekaragaman Makrozoobentos Sungai Lowatag Minahasa Tenggara Sulawesi Utara
}

\author{
Reinaldo E.Karuha, Ratna Siahaana*, Marina F.o Singkoha, \\ aProgram Studi Biologi, Fakultas Matematika dan IImu Pengetahuan Alam, \\ Universitas Sam Ratulangi Indonesia
}

K A T A K U N C I

Indeks Keanekaragaman

Shannon-Wiener,

makrozoobentos, Sungai

Lowatag, Sulawesi Utara

\begin{abstract}
A B S T R A K
Sungai memiliki peranan penting dalam kehidupan manusia dan mahluk hidup lainnya. Makrozoobentos menempati habitat di dasar sungai. Keanekaragaman makrozoobentos berperan penting pada ekosistem sungai. Penelitian ini bertujuan untuk menganalisis keanekaragaman makrozoobentos Sungai Lowatag berdasarkan Indeks Keanekaragaman Shannon-Wiener ( $\left.\mathrm{H}^{\prime}\right)$. Penelitian ini menggunakan metode purposive random sampling di sepanjang Sungai Lowatag. Stasiun penelitian sejumlah tiga stasiun yaitu hulu, tengah dan hilir dengan ulangan di tiap stasiun berjumlah tiga kali ulangan. Makrozoobentos yang ditemukan di Sungai Lowatag memiliki kelimpahan total sebanyak 1.115 individu (35 taksa). Kelimpahan makrozoobentos di Stasiun I, II, dan III berturut-turut yaitu 26,37\%, 44,39 \% dan 29,24\%. Nilai Indeks Keanekaragaman Shannon (H') dari Stasiun I, II dan III berturut-turut yaitu 2,97; 2,69; dan 2,61. Nilai H' untuk Sungai Lowatag yaitu 2, 94.

A B S T R A C T

Rivers have important role for humans and wildlife. Macrozoobenthos occupies habitat at the bottom of the rivers. Biodiversity of macrozoobentos is important in river ecosystem. This study aimed to analyze biodiversity of macrozoobenthos of Lowatag River based on the Shannon-Wiener Diversity Index ( $\left.\mathrm{H}^{\prime}\right)$. This study used a purposive random sampling method along Lowatag River. There were three research stations, namely upstream, middle and downstream with three replications each station. Macrozoobenthos found in the Lowatag River have total abundance of 1,115 individuals (35 taxa). The abundance of macrozoobenthos at Station I, II, and III were $26.37 \%, 44.39 \%$ and $29.24 \%$ respectively. The Shannon Diversity Index (H ') values of Station I, II and III respectively were 2.97; 2.69; and 2.61. The H' value of Lowatag River was 2. 94.
\end{abstract}

K E Y W OR D S

Shannon-Wiener Index, macrozoobenthos, Lowatag River, North Sulawesi
TERSEDIA ONLINE

31 Oktober 2019

\section{Pendahuluan}

Sungai merupakan suatu ekosistem perairan mengalir yang memiliki peranan penting bagi manusia dan organisme lainnya. Sungai memiliki fungsi ekologis seperti habitat berbagai organisme akuatik seperti ikan, udang, dan moluska. Sungai juga bernilai ekonomi sebab dapat dimanfaatkan oleh masyarakat untuk memenuhi kebutuhannya sebagai sumber air baik untuk kegiatan rumah tangga, pertanian, maupun industri (Siahaan et al, 2012).

Aliran Sungai Lowatag melewati hutan, perkebunan, dan pemukiman penduduk di Kabupaten Minahasa
Tenggara sebelum bergabung dengan Sungai Suhuyon yang merupakan sungai utama dari Daerah Aliran Sungai (DAS) Ranoyapo. Aktivitas penduduk yang bermukim di sepanjang Sungai Lowatag dapat mengakibatkan penurunan kualitas air Sungai Lowatag yang akan mempengaruhi kehidupan masyarakat dan juga organisme lainnya. Umumnya, pemantauan kualitas air sungai secara biologi dilakukan dengan penggunaan indikator biologi misalnya makrozoobentos.

Penelitian dilakukan untuk menganalisis keanekaragaman makrozoobentos Sungai Lowatag.

*Corresponding author: Jurusan Biologi Fakultas Matematika dan Ilmu Pengetahuan Alam Universitas Sam Ratulangi, Jalan Kampus Keleak Manado;

Email address: ratnasiahaan@unsrat.ac.id

Published by FMIPA UNSRAT (2019) 
Penentuan kualitas Sungai Lowatag berdasarkan Indeks Keanekaragaman Shannon-Wiener $\left(\mathrm{H}^{\prime}\right)$.

\section{Material dan Metode}

Penelitian dilaksanakan dari Oktober sampai November 2017. Penelitian dilakukan di Sungai Lowatag yang melintasi dua desa yaitu Desa Pisa dan Desa Suhuyon, Kecamatan Touluaan, Kabupaten Minahasa Tenggara, Sulawesi Utara ( Gambar 1). Stasiun I terletak di Desa Pisa, Stasiun II terletak diantara Desa Lowatag dan Desa Suhuyon dan Stasiun III terletak di Desa Suhuyon. Identifikasi sampel makrozoobentos dilakukan di Laboratorium Ekologi, Fakultas Matematika dan IImu Pengetahuan Alam, Universitas Sam Ratulangi, Manado.

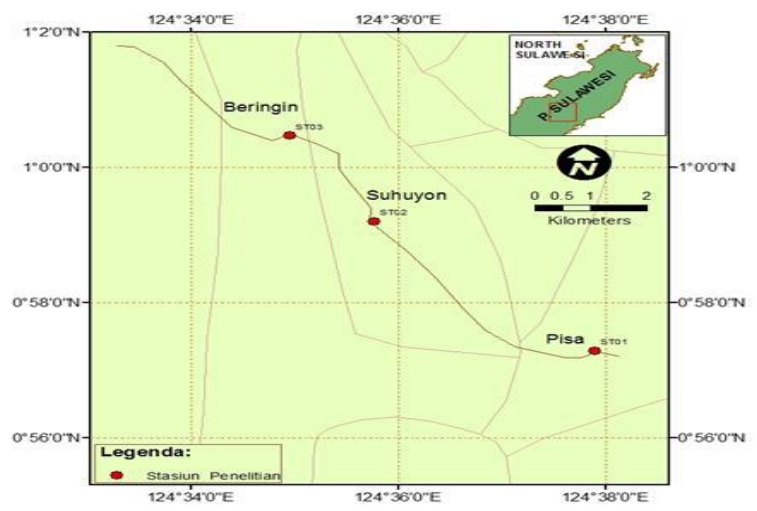

Gambar 1. Lokasi Penelitian (Patty, 2018).

Metode yang digunakan dalam pengambilan sampel makrozoobentos yaitu metode purposive random sampling ialah metode pencuplikan yang dilakukan secara sengaja oleh peneliti (Fachrul, 2007). Pengambilan makrozoobentos dilakukan dengan menggunakan jala surber berukuran $25 \mathrm{~cm}$ x $45 \mathrm{~cm}$ yang dilakukan di sisi kiri, tengah, dan kanan sungai. Sampel makrozoobentos berjumlah sembilan (9) sampel yang berasal dari tiga (3) stasiun dan tiga (3) ulangan dari tiap stasiun. Pengambilan sampel dengan cara menempatkan jaring surber menghadap ke arah datangnya arus.

\section{Hasil dan Pembahasan}

Kelimpahan makrozoobentos di Stasiun I sebanyak 294 individu (29 taksa), Stasiun II sejumlah 495 individu (25 taksa), dan Stasiun III sebanyak 326 individu (22 taksa). Kelimpahan total makrozoobentos yang ditemukan di Sungai Lowatag sebesar 1.115 individu (35 taksa).

Taksa tertentu akan meningkat atau menurun kelimpahannya jika lingkungannya mendukung atau kurang mendukung pertumbuhannya. Aktivitas penduduk akan mempengaruhi kekayaan taksa makrozoobentos. Peningkatan aktivitas penduduk dari hulu ke hilir akan menyebabkan penurunan kekayaan taksa. Aktivitas penduduk dari hulu ke hilir.

Stasiun II terletak di bagian tengah Sungai Lowatag dengan tutupan vegetasi yang lebih rendah dibandingkan Stasiun I. Perubahan tutupan lahan ini akan menyebabkan peningkatan kelimpahan taksa tertentu terutama Heptagenidae sebanyak 178 individu dibandingkan di Stasiun I (67 individu) dan Stasiun III (15 individu). Taksa Paraleptoplebia juga menyumbang terhadap tingginya kelimpahan di Stasiun II (58 individu) dibandingkan di Stasiun I (13 individu) dan Stasiun III (2 individu).

Kekayaan taksa makrozoobentos semakin menurun dari hulu menuju hilir. Kekayaan taksa makrozoobentos Stasiun I lebih tinggi dibandingkan Stasiun II dan III. Kekayaan taksa makrozoobentos di Stasiun I, II dan III berturut-turut yaitu 38,16\%, 32,89\% dan 28,95\%.

Nilai Indeks Keanekaragaman Shannon ( $\left.\mathrm{H}^{\prime}\right)$ dari Stasiun I, II dan III berturut-turut yaitu 2,97; 2,69; dan 2,61. Nilai H' untuk Sungai Lowatag yaitu 2,94 (Gambar 2). Nilai H' dari Stasiun I yang terletak di bagian hulu semakin menurun menuju hilir di Stasiun III.

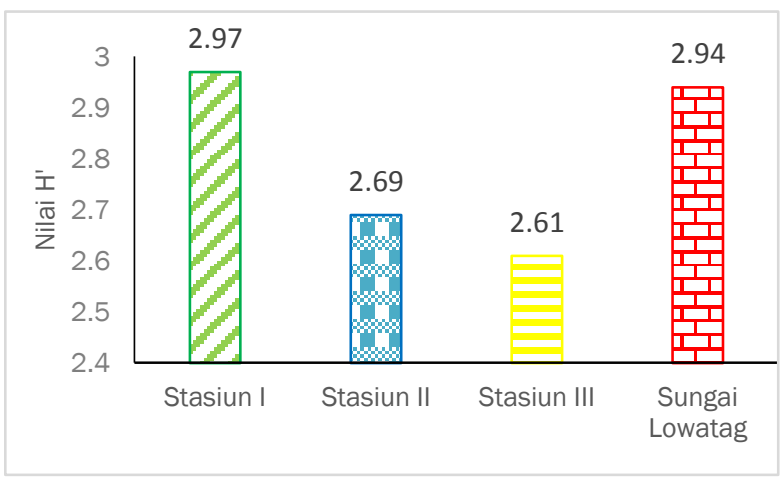

Gambar 2. Indeks Keanekaragaman Makrozoobentos

Tingkat keanekaragaman makrozoobentos dari Stasiun I, II dan III termasuk sedang. Makrozoobentos peka terhadap cekaman ataupun perubahan lingkungan baik secara alami maupun buatan akibat manusia. Perubahan lingkungan akan menyebabkan perubahan struktur makrozoobentos pada badan perairan (Putro, 2014). Kemampuan makrozoobentos ini disebabkan seluruh hidupnya di dalam sistem perairan sehingga perubahan lingkungan air sungai akan tampak.

\section{Kesimpulan}

Keanekaragaman makrozoobentos berdasarkan Indeks Shannon-Wiener (H') berturut-turut dari Stasiun I, II, dan III yaitu 2,97; 2,69; dan 2,61. Keanekaragaman makrozoobentos Sungai Lowatag tergolong sedang dengan Nilai H' yaitu 2, 94 
Daftar Pustaka

Fachrul, M. F. 2007. Metode Sampling Bioekologi. Bumi Aksara, Jakarta.

Patty, J.O. 2018. Kehadiran dan Distribusi Logamlogam Berat ( $\mathrm{Pb}, \mathrm{Cd}, \mathrm{Cu}$, dan $\mathrm{Zn}$ ) pada Air dan Sedimen serta Faktor-faktor Fisika dan Kimia Sungai Lowatag, Sulawesi Utara [skripsi]. Jurusan Biologi, Fakultas Matematika dan IImu Pengetahuan Alam, Universitas Sam Ratulangi, Manado.

Putro, S.P. Metode Sampling Penelitian Makrobenthos dan Aplikasinya. Graha IImu, Yogyakarta.

Siahaan, R., Indrawan A., Soedharma D. dan Prasetyo L. 2012. Kualitas Air Sungai Cisadane, Jawa Barat-Banten. Jurnal Imiah Sains 11 (2): 268-272. 